\title{
CLOUd COMPUTING ACTIVITIES: SOUTH AfRICAN NORMAL TAX SOURCE DETERMINATION
}

\author{
Rudie Nel* \\ Stellenbosch University
}

Received: March 2015

\author{
Shene Steenkamp * \\ Stellenbosch University
}

Accepted: March 2016

\begin{abstract}
The location-independent nature of cloud-based transactions results in many source-related difficulties for normal tax purposes. This study considered the source determination for each of the possible classifications of cloud-based income (lease, service and royalty income, and/or income from know-how) by performing a doctrinal study based on South African and international literature. This study identified and formulated the challenges in applying traditional source tests in the context of cloud-based transactions. These challenges stem from the potential absence of physical presence of the provider in the country of consumption, in contrast to traditional source tests where physical presence indicate a tax presence; as well as the location-independent nature of cloud-based transactions from the perspective of both the provider and the consumer. The findings of the study suggest that the source determination for cloud-based transactions could be based on the source of the payment or residency of the payer, rather than the physical location.
\end{abstract}

Keywords

Source rules, cloud-computing, originating cause, section 9 , income tax

*Mr R Nel is a senior lecturer in the School of Accountancy, Stellenbosch University, South Africa. [rnel@sun.ac.za]

*Ms S Steenkamp is a lecturer in the School of Accountancy, Stellenbosch University, South Africa. 


\section{INTRODUCTION}

The Internet has exponentially accelerated the trend of cross-border economic activity. The cloud computing phenomenon represents a further refinement of doing business via the Internet, which can make the location of profits even harder for tax authorities to pin down (Joubert, 2012). The Fifth Interim Katz Commission Report (1997) recognised that 'electronic commerce developments will greatly affect some of the basic tenets of international taxation, for example, the irrelevance of physical presence in order to trade (impacting on "permanent establishment" concepts), the ease with which current residence notions can be manipulated through hyper-mobility of an entire office and trading or management capacity, and the manner in which goods or services can be contracted for, advertised and even delivered by electronic means'.

Cloud computing represents an extension of information technology (IT) outsourcing whereby users benefit not merely from the use of enhanced IT functions, but may also distance themselves from ownership of computer resources (Smith \& Clearley, 2012). Consumers are granted network access to cloud infrastructures to obtain the value of the IT capabilities made available by cloud service providers (CSPs). Internet technologies are, therefore, essential in the utilisation and delivery of cloud computing activities. The 'use of' the resources of CSPs has raised questions internationally on the classification of cloud computing activities according to the form thereof as a service (Ernst \& Young, 2012). The Internet has established a platform where computer resources and capabilities are delivered and consumed through the cloud, independent of the location of both the provider and the consumer (Bradshaw, Millard \& Walden, 2011). From the consumer's perspective, location independence means that cloud activities can be consumed from anywhere in the world, provided a consumer has access to the Internet (Bradshaw et al., 2011). From the CSP's perspective, location independence means that computer resources can be positioned and set up wherever this is most effective and where economies of scale can be exploited (Bradshaw et al., 2011).

However, it is precisely this location independence that lies at the root of tax difficulties, since it allows for the consumption of cloud computing at a location where the physical presence of the CSP is not required. Generally, physical presence (i.e. the existence of infrastructures) gives rise to a tax source in a country (Joubert, 2012). Cloud computing may therefore result in CSPs conducting ample economic activity within a country with little or no physical presence there, as the infrastructure is situated in another (tax) beneficial country (Joubert, 2012). This necessitates a re-examination of the identification of the tax source determination of cloud computing activities based on physical presence, in order to avoid potential tax losses.

From the aforementioned it is evident that cloud computing activities result in computer resources being used via the Internet independent of a specific location, which clearly causes normal tax uncertainties. Such tax uncertainties may have possible adverse consequences for the South African fiscus if they are not addressed. The failure to highlight and address the uncertainties related to the normal tax treatment of cloud computing may lead to possible tax and government income losses (KPMG International, 2012). Tax losses may prove to be significant, since it is estimated that total spending on cloud services worldwide will amount to $\$ 210$ billion in 2016 (Clearley, Scott, Skorupa \& Bittman, 2013). South Africa is no exception to this technological phenomenon of cloud computing and is, therefore, not excluded from the risk of potential tax leakages. According to Kshetri (2010), the consumption of cloud computing services in developing countries is small, but growing fast and it is primarily concentrated in big economies such as South Africa. 
At present the Internet enables non-resident CSPs to conclude business transactions with South African residents with no physical (tax) presence in the country. However, limited studies from a South African perspective have been conducted to determine whether or not non-resident CSPs do, in fact, incur normal tax liabilities for such activities. Anecdotal evidence from Joubert (2012) and KPMG International (2012) suggests only the possible taxation uncertainties caused by cloud computing. While extensive academic research on cloud computing as a technology has been conducted, attention is called to the need for certainty regarding the normal tax treatment of cloud computing transactions from a South African perspective.

An investigation into the normal tax source of cloud computing activities could assist in identifying the normal tax source of such services. If it is found that these services originate from a source in South Africa, taxation could then be applied in an attempt to prevent tax leakage as result of the cloud computing industry. It is recognised that National Treasury (2014) issued a draft regulation in respect of the Value-Added Tax (VAT) regarding electronic services after the initial effective date of 1 April 2014 was postponed. It has yet to be determined whether the cloud computing services would require of non-resident CSPs to register for VAT in South Africa. This point could therefore serve as a recommendation for further future research. It is submitted that, even if non-resident CSPs become liable for VAT in respect of cloud computing services in future, such liability would not preclude these transactions from a normal tax liability and would therefore not affect the value of the findings of this study.

\section{RESEARCH OBJECTIVE AND RESEARCH METHODOLOGY}

The objective of this study was to perform a source determination of income from cloud computing activities. The objective was achieved by the identification of the applicable legal requirements contained in the Income Tax Act No. 58 of 1962 (the Act); analysis of the issue(s) from a legislative point of view using case law and other available literature, and an explanation of areas of difficulty in the income source determination of cloud computing services. The research strategy followed is doctrinal in nature and is described by Hutchinson and Duncan (2012:101) as 'research which provides a systematic exposition of the rules governing a particular legal category, analyses the relationships between rules, explains areas of difficulty and, perhaps, predicts future developments'.

This research adds to the extant literature by investigating the source determination of cloud computing income from a South African context. No other similar studies were noted during the performance of the study. Furthermore, this study postulated issues identified in respect of such source determination. These issues could assist in attempts to align taxation laws and thereby embrace the change in cross-border economic activities within the Internet realm.

The source determination is dependent on the nature of the income. Income earned from cloud computing activities may be classified as either lease income from tangible, moveable computing resources; service income and/or royalty income (the latter includes its closely related income from know-how) or a combination of the aforementioned (Steenkamp, 2014). The different classifications would be affected by the terms of the agreement and the specific service model (Infrastructure as a Service, Platform as a Service or Software as a Service). Lease and service income fall outside the scope of section 9 of the Act, which describes source rules for a list of income categories. Consequently, the applicable source determination thereof is based on common law doctrines of which the test of originating cause (Commissioner of Inland Revenue $v$ Lever Brothers and Another 1946 AD 441, 1946) (hereafter referred to as the Lever Brothers case) 
is widely accepted as fundamental to source determination. Contrary to lease and service income, royalty income and its closely related income from know-how are encompassed in the list of normal tax classifications and relevant source determination of section 9 of the Act.

The research strategy relied on literature related to source determination pertaining to the various normal tax classifications of cloud transactions, as indicated in FIGURE 1, which also includes references to the relevant section $(\S)$ in this study:

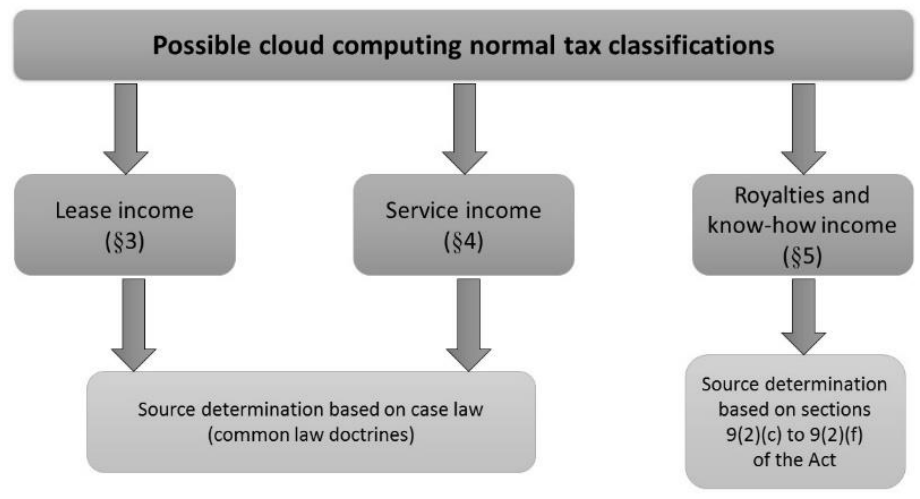

\section{FIGURE 1: Research strategy}

Source: Authors' summary of the research strategy

\section{LEASE INCOME}

Income received for the provision of cloud-based computer hardware that results in the consumer having significant control over such hardware and where the parties to the agreement wilfully intend such a transaction to be a lease, may be considered for the lease income classification (Steenkamp, 2014). The omission of lease income from tangible resources in the list of income classifications in section 9 of the Act implies that the source determination for such normal tax classification should be determined by common law doctrines. In this regard, the test of originating cause was authoritatively laid down in the Lever Brothers case (Van Zyl, 2015). The originating cause, and its location, of lease income have traditionally been determined by firstly regarding the nature of the asset (moveable or immoveable) generating the income. Cloud computing agreements could provide access to, and the use of, computer hardware, which by nature constitute moveable assets, resulting in the effective lease of a moveable asset. In the case of Commissioner of Taxes v British United Shoe Machinery (SA) (Pty) Ltd 26 SATC 163 (1964) (hereafter referred to as the British United case) it was held that the originating cause of a lease of a tangible asset is identified based on the object of emphasis of lessors, which can either constitute his/her business or his/her lease asset. The emphasis on either one of these objects is indicated by considering two elements - the duration of the lease and whether or not the lessor is concerned with where the lease asset is used (Meyerowitz, 2005). Leases that are of short duration or vary in duration generally indicate that the object of emphasis and the resultant location of the originating cause are the business of the lessor. In contrast, longer lease terms could imply that the lease asset is the object of emphasis. Consequently, the latter indicates that the source of the lease income is where the asset is located if the lessor is concerned with where the lease asset is used. Alternatively, if the emphasis is not on the asset, but rather on the business of the 
lessor, then the source would be where the business is carried on and not where the asset is being used (Van Zyl, 2015). These guidelines and elements are summarised in FIGURE 2.

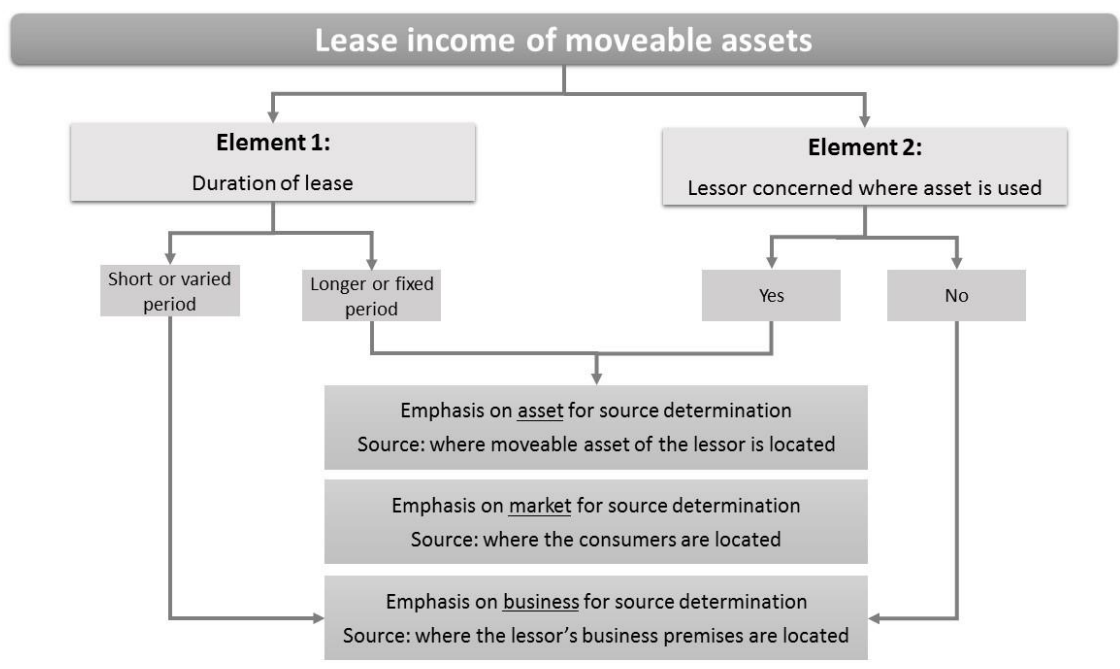

\section{FIGURE 2: The source determination of lease income from moveable assets}

Source: Authors' summary of the source determination of lease income from moveable assets

This study postulates that the judgement in the British United case (1964) renders many arduous questions relating to the test of source for lease income within a cloud computing environment. As a starting point, it is essential to enunciate the predominant divergence from a traditional lease referred to in the British United case (1964) to a modern cloud computing lease. Traditionally lessees have physical possession of (or access to) leased assets, which implies that the physical location of the leased assets and the use thereof are inseparable. In the cloud computing context the lessees do not have physical possession of (or access to) the leased assets, but rather execute the right to use leased assets remotely via the Internet. This implies that the physical location of the leased assets and the use thereof are separable. This separation of use and possession within the cloud computing milieu grounds the inquest into various uncertainties pertaining to the applicability of the common law doctrines established in the British United case (1964).

The doctrinal research performed in this study postulates two areas in which cloud computing differs from the accepted interpretation of the British United case (1964): (1) the importance of the location of the market for goods and (2) the meaning of 'concerned with' for the purpose of the second element in FIGURE 2.

\subsection{The importance of location of market for goods}

Vis-à-vis FIGURE 2, the object of the lessor's emphasis has traditionally been narrowed down to either the location of the asset or the business premises of the lessor, with the location of the asset also being where the consumer exercises the right to use the leased asset. Consequently, at the time of the judgement, the need to distinguish between the location of use and the physical location of the asset was irrelevant. However, within cloud computing such a distinction seemingly becomes more relevant. The separation of the physical location and use of assets 
necessitates the consideration of a third prospect regarding the lessor's object of emphasis, namely the location of the market for goods. The consideration of this additional possible object of emphasis within a cloud computing environment is reinforced by an account in the British United case (1964), which states that when property produces income in a market, the source of that income lies where the market is concerned.

The economic interpretation of 'market' refers to a group of consumers to which an enterprise aspires to make its products or services available. Alternatively, it can also refer to the location where the enterprise promotes the supply of its products or services, for example, a specific geographical area to which the service or product is made available. From the widely used definition of cloud computing by the National Institute of Standards and Technology (NIST), according to Mell and Grance (2011), it is evident that cloud computing makes computer resources available to consumers at their convenience, wherever they may find themselves. The location of the consumer, which is where the cloud is accessed to exercise the right to use the computing infrastructure, may conceivably represent the market for cloud activities. The assertion that the market should be considered to be the source of lease income did not create any difficulties within a traditional lease, where a single location exists for the physical asset and its use. This may have resulted in the significance of this account being disregarded with traditional lease source determination. Considering the market, i.e. the location of the consumer, as the object of emphasis of Internet commerce transactions was also alluded to in Casino Enterprises (Pty) Ltd $v$ The Gauteng Gambling board (2011) (hereafter referred to as the Casino Enterprise case), where it was argued that the provider of online gambling is essentially making such games available to South Africans, which results in online gambling taking place in South Africa. Evidently the judgement from the Casino Enterprise case (2011), in tandem with the potential reinterpretation of British United case (1964), may then result in the location of the market, that is, the location of the consumer, being considered as an optional object of emphasis to the CSP (lessor) within a cloud-based lease environment.

The supplementary consideration of the location of the market as an object of emphasis creates a number of reservations related to the traditional two indicative elements, as designated in FIGURE 2. The relevance and intended meaning of the two elements designated to be indicative of the object of emphasis evidently become questionable if the location of the market is considered. The business premises and the location of the market of a CSP are separated from each other. Furthermore, the location where the assets are situated is also separated from the users of the cloud computing assets. Clearly, these reservations result in the need for guidance on the sourcing of cloud-based lease transactions. In addition, the intended meaning of 'concerned with' in the second element designated in FIGURE 2 also results in sourcing uncertainties.

\subsection{The meaning of 'concerned with' in source determination of lease income}

The second indicative element, whether or not the lessor is concerned with where the asset is used, also becomes debatable under the faculty of cloud computing. In the context of the British United case (1964:167), the attitude of the lessor towards the location of the use of the lease asset, is described as '...the lessor of the property was concerned with where his machines were to be used...' Once again, no distinction was required in the event of a traditional lease. However, 'concerned with' is inherently vague and, within the context of cloud computing, what follows this prefix, i.e. either the location of the consumer or the asset, may be determined by the degree or strength of the lessor's concern and the perceived meaning of 'concerned with'. 
One potential approach to this quandary may lie in the interpretation of 'concerned with' as 'having control over', especially since control over the lease assets is an essential element in the classification of income, specifically lease income (Van der Walt \& Pienaar, 1999). This interpretation is merited based on the two opposing leases compared in the British United case (1964). In said case, the lessor has control over where the assets are used by means of a condition in the lease agreement, which specifies where the lease assets may be used and located. This is compared to the lease of vehicles, where the lessor has no such control as a result of the nature of such business - a logical result as the lessee of the vehicle can freely move the vehicle wherever required. Accordingly, it may be argued that being 'concerned with' is a consequence of firstly having 'control over', which has traditionally been narrowed down to controlling the location where the asset is used, which also inherently implies control over the physical location of the asset. Although the British United case (1964) specifically refers to where the asset is used, at the time of the judgement, the need to distinguish between control pertaining to the location of use and the physical location of the asset was irrelevant. However, within cloud computing such a distinction seemingly becomes relevant as the CSP (lessor) has no control over where the computing resources are used by the consumer (lessee) due to the location-independent nature of Internet activities.

Evidently, guidance on the perceived meaning of 'concerned with' is needed to ensure the appropriate normal tax source determination of cloud computing lease income, i.e. whether or not 'concerned with' in the context of the doctrine set in the British United case (1964) could be interpreted as 'having control over'. If the latter is affirmed, it should also be determined whether control relates to the location of use of the lease asset or the physical location of the lease asset itself.

\subsection{Issues identified in source determination of lease income}

It is recognised, in agreement with Van Zyl (2015), that there are risks in generalising cases in source determination and that each case should be considered on its own merits. The findings based on the principles of the British United case (1964) are thus not submitted as conclusive, but rather as indicative of possible uncertainty in the application in the context of cloud computing. Although the market of CSPs extends worldwide, this all-inclusive market does inherently include South Africa and that lease income earned by CSPs from South African consumers should incur South African normal tax liabilities. This statement does not create any difficulties within a traditional lease, where a single location exists for the physical asset, the use of the asset and the market. However, a cloud computing environment allows for the asset and the use of the asset to each have different and continually changing locations. A traditional lease characteristically allows for only two possible locations to be considered as the source, namely the business premises of the lessor and the location of the asset, the latter being interchangeable with the location of the consumer using the asset. Consequently, the elements designated in FIGURE 2 are considered relevant to pinpoint the originating cause of a traditional lease of moveable property, but ignore the location of the market for the cloud computing services.

Issues that relate specifically to the normal tax source determination of cloud-based lease activities are summarised in TABLE 1 where it highlights the need for guidance on a standardised treatment of cloud computing activities. 
TABLE 1: Issues identified relating to source determination of lease income

Importance of location of market for lease income

The potential separation of the locations related to the asset, the use thereof and the business premises of the CSP within cloud-based lease agreements are all important considerations, which were not applicable in the case of traditional lease agreements. The location of the market (i.e. the physical location of the consumer) for goods is submitted as an important consideration and it is not certain whether this consideration could be interpreted above the well-established elements of lease term and control due to the very different nature of cloud computing activities, compared to traditional leases. Guidance is this regard is fundamental to establishing the source of cloud lease activities.

Location of market implies the physical location of consumers

Source determination based on the physical location of consumers could render certain administrative difficulties (elaborated on in $\S 4$ ).

Source: Authors'deduction

The next line of inquiry will be the source determination of service income.

\section{SERVICE INCOME}

The seminal court cases in the determination of the source of service income are Commissioner of Taxes v Shein 1958 (3) SA 14 (FC) (1958) and the Lever Brothers case (1946). The traditional view held in Commissioner of Taxes v Shein 1958 (3) SA 14 (FC) (1958) is that the source would be the place of performance, including accepting responsibility for such performance. In the context of cloud computing, the place of performance may be difficult to determine as non-resident CPSs may render services from different locations (for example, have a head office in one place, render services using servers situated in another place and a consumer situated in neither of the aforementioned places). Due to the problematic source determination of service income, SARS (2013) stated that, unlike physical services, it may even be impossible to determine the place of performance of an electronic service. This statement in itself provides suitable grounds to question the authority of the traditional source approach to services within the Internet realm, and specifically to this study, the approach to the cloud computing milieu. With reference to electronic commerce, Oguttu and Van der Merwe (2005) recommend that a distinction may have to be drawn between several variables, for instance, where the input is produced, where the server provides the input to the consumer or where the program interacts with the consumer. This distinction in itself, however, does not guarantee that the dominant cause of cloud service income can be identified or located. In the Lever Brothers case (1946) it was held that the source of income is established by firstly determining the originating cause (that is, what the taxpayer does to produce the income) and then by locating that cause. Ultimately it seems that, within the parameters of the originating cause test, that which the consumer is paying for in cloud computing transactions could be indicative of the dominant source. This approach was also followed in the Casino Enterprise case (2011) in determining the location of Internet gambling, where it was interpreted that the location is where the main concept/substance of online gambling takes place and that aspects irrelevant to the substance can be ignored in considering such location. In applying the approach held in the Casino Enterprise case (2011), it appears that the originating cause of cloud services may be identified by answering the question as to where 
the concept of cloud computing services comes to pass. In this regard, two alternative arguments regarding the source of cloud service income were formulated, based on: (1) the physical location of the consumer (literal approach) and (2) the source of payment or residency of the consumer (broad approach).

\subsection{Physical location of the consumer (literal approach)}

Cloud computing is, in a summarised version, the provision of computer resources to consumers at their own convenience, wherever they find themselves, with minimum management effort or service provider interaction (Mell \& Grance, 2011; Plummer, Smith, Bittman, Clearley, Cappuccio, Scott, Kumar \& Robertson, 2009). A service is not a function, it is a function performed on the consumer's behalf at a cost to the consumer (0'Sullivan, Edmond \& Ter Hofstede, 2002). The service provider uses its skills to render this function $(0 \varepsilon C D, 2012)$ to deliver value to consumers by facilitating consumer-defined outcomes without the ownership of specific costs and risks (ITIL, 2011). Furthermore, service rendering also includes the acceptance of responsibility, as held in Commissioner of Taxes v Shein 1958 (3) SA 14 (FC) (1958). It should be borne in mind that cloud computing is a specified form of electronic service rendering. The fact that an electronic service can automatically be summoned at any given time and location (0'Sullivan et al., 2002) is therefore very relevant to this analysis.

Based on the aforementioned, it is posited that the concept, the essence, of cloud computing services could be digested as follows: the CSP accepts a responsibility to perform the function of providing consumer-defined computer resources wherever the consumer may summon them, which is also where the value is delivered to the consumer. The location of both the acceptance of the responsibility by the CSP, as well as the act of provision is determined by where the consumer is at the time when the cloud service is summoned. It is submitted that the concept of cloud computing therefore comes to pass where the consumer is located and it may even be argued that this could ultimately be what the consumer is paying for. In the latter statement, the activities performed by the CSP at either its place of business or the location of the servers is not disregarded, but merely viewed as immaterial or incidental to the dominant originating cause of the cloud income generated by the provision of computer resources at their own convenience, wherever they may find themselves. However, the location-independent nature of cloud computing makes the isolation of one location of the consumer problematic, which results in the following alternative argument for the source of cloud service income, i.e. the source of payment or residency of the consumer.

\subsection{Source of payment or residency of the consumer (broad approach)}

A challenging quandary may arise in identifying the physical location of the consumer at the time when a cloud service is summoned. This difficulty stems from the electronic delivery of cloud computing, which enables the consumer to access and use a cloud from different locations, wherever an Internet connection is present. However, for the purposes of locating a place of supply for VAT compliance, SARS suggests a broad approach to address this difficulty by using proxy addresses for locating consumers of electronic services (SARS, 2013). According to these proxy addresses, the consumer of electronic services is regarded to be located in South Africa either if the source of the payment is from a South African bank account or if the consumer is a South African resident - therefore disregarding the physical location of the consumer. Placing the focus on the source of the payment or residence of the consumer, and not the physical location of the consumer, also eliminates various interpretation problems. The most prevalent interpretation 
problem is that non-resident CSPs will be liable for South African normal tax if any person, including non-residents, connects to the Internet to access or use cloud activities from a South African address while being physically present in South Africa. This brings forth implicit, copious administration and practical difficulties in tracking consumer locations and apportioning income earned by CSPs to all countries in which consumers are physically located.

However, this broad approach and the use of proxy addresses are not without fault when they are related to the source of income for normal tax purposes. There are various limitations to the assumptions made under this broader approach. It is assumed that the CSPs will have this information disclosed to them and that reliance can be placed on the CSP to comply with the South African normal tax liability imposed on them for consumers located there (Hellerstein \& Sedon, 2012). It is also assumed that the use of the consumer's information will not constitute bad faith (Hellerstein \& Sedon, 2012). The assumption is also made that the ultimate consumer of the computing resources provided in cloud computing transactions is located at these proxy addresses, rather than merely the account financier (Hellerstein \& Sedon, 2012). Furthermore, uncertainty regarding citizenship/company registration and tax residency according to section 1 of the Act may exist. If, in particular, the tax residency of a consumer is not disclosed to the CSP, it will result in certain transactions escaping the CSP's South African normal tax liability. Ultimately, the source determination of cloud-based service income is tainted with various uncertainties.

\subsection{Issues identified in the source determination of service income}

According to Wesson (1999), the source of service income would be where the services are rendered and the physical place of business of the service provider could be indicative of where such services are rendered. However, the business premises or server plants of non-resident CSPs are likely to be situated outside South Africa. This may result in various economic activities being conducted with South African residents with little or no physical presence and, consequently, no normal tax consequences, which may ultimately defy the purpose of source tests. This study formulated potential alternative approaches to the identification and location of the originating cause of service income within the cloud computing environment. These approaches are not without fault and the issues identified are summarised in TABLE 2.

In conclusion, it is submitted that the optimal approach in establishing the source of cloud-based service income would be to base it on the source of payment for such services or residency of the consumer - and not the physical location of the consumer. This submission could also be indicative of the location of the market for such services and therefore corresponds to the conclusion reached in respect of lease income.

The next line of inquiry will be the source determination of royalties and know-how income.

\section{ROYALTIES AND INCOME FROM KNOW-HOW}

The source determination of proper royalties and the imparting of know-how are covered under sections $9(2)(c)$ to $9(2)(f)$ of the Act. Sections $9(2)(c)$ to $9(2)(d)$ of the Act relate to proper royalty income and sections $9(2)(e)$ to 9$) 2$ )(f) of the Act relate to the imparting of know-how (scientific, technical, industrial or commercial information and ancillary services in connection with such knowledge). 


\section{TABLE 2: Issues identified relating to source determination of service income}

The physical location of the consumer

The location-independent nature of cloud computing makes the isolation of one specific location for the physical presence of the consumer difficult. It is considered impractical to track customer locations and apportion income earned by CSPs to all countries in which consumers may be present at the time of use.

Source of payment or residency of consumer

According to Hellerstein and Sedon (2012), various limitations exist under this approach, since the use of proxy addresses assumes that:

- the CSPs will have this information disclosed to them;

- reliance can be made on the CSP to comply with the South African normal tax liability imposed on them for consumers located there;

- the use of the consumer's information will not constitute bad faith; and

- the ultimate consumer (and not account financier) is located at the proxy addresses.

Furthermore, uncertainty may exist regarding citizenship/company registration and tax residency according to section 1 of the Act. If the tax residency of a consumer is not disclosed to the CSP, it will result in certain transactions escaping the CSP's South African normal tax liability.

Source: Authors' deduction

However, the respective sections on proper royalty income and income from know-how both describe the same two-part source test for each of these income categories. This two-part source test firstly entails that these income categories are from a South African source if the remunerating party is a South African resident, unless the receipt is attributable to a permanent establishment outside South Africa. Secondly, South African source royalties and know-how income will exist if the receipt is related to the use, right of use, or granting of permission to use intellectual property or know-how within South Africa. Consequently, the source rules relevant to both proper royalties and know-how will be studied uniformly under the faculty of this two-part test.

The first test of the two-part source test is based on payments that are made by South African residents. In the context of this study, which excluded research on the existence and location of a permanent establishment of the CSP in South Africa, this test is evidently self-explanatory and uncomplicated. Consequently, the first test of source in sections $9(2)(c)$ to $9(2)(f)$ of the Act requires no further examination. Importantly, these statutory provisions agree with the findings under the source determination of service income.

In contrast, a challenging quandary may arise in the second source test in sections $9(2)(d)$ to $9(2)(f)$ of the Act, which is based on intellectual property and know-how that are used in South Africa. Logically, the intellectual property and know-how are used where the consumer is located and it stands to reason that the location of the consumer should be established according to the same broad approach described in $\S 4$, which renders similar issues.

\subsection{Issues identified in the source determination of royalties and income from know-how}

The source determination according to the classification of royalties and income from know-how presents a number of issues. These issues are presented in TABLE 3. 
TABLE 3: Issues identified relating to source determination of royalties and income from knowhow

Interpretation of 'used in South Africa' in the context of the secondary test in sections 9(2)(c) to $9(2)(f)$ of the Act

Uncertainty exists as to whether the second test of sections 9(2)(c) to 9(2)(f) should be interpreted based on a literal (physical presence and use in South Africa) or broader (used by a South African resident) approach. From SARS (2013) correspondence related to VAT on electronic services, it seems that the broader approach is preferred. The application of a source determination approach based on the source of the payment or residency of the consumer (and not the physical location of the consumer) eliminates many administrative difficulties that are associated with the literal approach in establishing the physical location of the consumer, as described under $\S 4$.

Uncertainty regarding the scope of scientific, technical, industrial or commercial information referred to in sections $9(2)(e)$ to $9(2)(f)$ of the Act

It is unclear what is included within the scope of scientific, technical, industrial or commercial information referred to as know-how in sections $9(2)(e)$ to $9(2)(f)$ of the Act. Since cloud computing is a technology, it has been assumed that cloud activities may be of a technical nature. However, greater clarity is required in this regard.

Uncertainty regarding the level of flexibility implied by the words 'in connection with' in sections 9(2)(e) to $9(2)(\mathrm{f})$

The words 'in connection with' refer to the connection between the know-how itself and ancillary services. Consideration must be given to whether the service or assistance should merely be related, or should be essential, to the application of know-how.

Source: Authors'deduction

\section{CONCLUSION}

The nature of cloud computing activities, which are conducted via the Internet, raises many difficulties related to tax source determination. The primary taxation-related problems are elicited by the composition of these activities, namely the provision of the cloud by the service provider via the Internet and the subsequent use thereof by the consumer at any worldwide location he/she finds most convenient. This composition causes the taxation source determination to become problematic. Yet, from a South African perspective, little assistance exists in terms of these problems. As a result, significant income may escape South African taxation liabilities. The aim of this study was to investigate South African taxation source determination related to cloud computing agreements. The findings of this study are summarised in this section. The findings are organised according to the possible normal tax classifications of cloud computing activities and the subsequent potential tax source determination applicable to each classification.

Lease income: Cloud activities will only be classified as a lease if it is established that the consumer both controls the underlying computer hardware and wilfully intends such control (Steenkamp, 2014). In the event of cloud activities being classified as a lease, the source determination relies on the South African common law doctrines, which primarily stem from the doctrine of originating cause. A summary of the potential elements that may be indicative of the 
source of lease income, extracted from the British United case (1964), is articulated in FIGURE 2. Issues identified in the source determination of lease income are summarised in TABLE 1.

Service income: Cloud activities that do not result in lease, royalty or know-how income are, by omission, classified as service activities. The nature of services rendered via the Internet necessitates a reassessment of the traditional source test, namely where services are rendered. However, such reassessment should be performed within the parameters of the originating cause relating to cloud computing. Furthermore, it seems clear from the Casino Enterprise case (2011) that this is achieved by considering and describing the concept of cloud computing, namely the acceptance of responsibility by the CSP and the provision of computer resources to consumers wherever they are summoned. The location where all the above-mentioned elements of cloud computing come to pass is where the consumer is located. Therefore, if cloud services are used by residents, it should result in a South African normal tax liability to non-resident CSPs. It is also posited in this study that the same broader approach to royalties also applies to services that are consumed in South Africa. Issues identified in the source determination of service income are summarised in TABLE 2.

Royalties and income from know-how: The factors that should be considered in establishing whether cloud activities earn either royalties or income from know-how are contained in sections $9(2)(c)$ to $9(2)(f)$ of the Act. Cloud activities will generally result in payment for the use of IP or know-how, rather than the actual IP or know-how itself. This implies that the use of IP or knowhow within a cloud context will commonly not fall within the scope of sections $9(2)$ (c) to 9(2)(f), since they will be classified as services. In the event of income as a result of cloud computing being categorised as rendering proper royalty income or the imparting of know-how, the source determination is performed based on the two-part test described in sections $9(2)$ (c) to 9(2)(f). Issues identified in the source determination of royalties and income from know-how are summarised in TABLE 1 .

The intricate nature of cloud computing activities requires vigilant investigations relating to the test of source, with the intention of preventing possible significant loss of normal tax for the South African fiscus. Traditionally, the South African courts have dominantly established originating cause based on the so-called activities test (Meyerowitz, 2005), i.e. where the taxpayer performed the actions that resulted in his/her receiving income (Commissioner of Inland Revenue $v$ Epstein 1954 (3) SA 689(A), 1954). However, in the dissenting judgement in Commissioner of Inland Revenue $v$ Epstein 1954 (3) SA 689(A) (1954) the opinion was held that it was not the intention of the judgement in the Lever Brothers case (1946) to always assume that the activities test is applicable in determining the originating cause. It was stated in the dissenting judgment that the originating cause may also be where profits are realised (Commissioner of Inland Revenue $v$ Epstein 1954 (3) SA 689(A), 1954). In the context of cloud computing this could possibly be construed as the location of the market (where the consumer is located). In terms of source determination, the shift in focus to the location of the consumer (paying for the services) is also evident in the amendments to sections 9(2)(b),9(2)(c) and 9(2)(e) of the Act.

The findings of this study suggest that the source determination for cloud computing activities could be based on the source of the payment or residency of the payer, rather than the physical location of the consumer. These findings would also be in line with recent VAT amendments in respect of electronic services, which form the basis for the levying of VAT. Furthermore, the recent introduction by the OECD (2015) of the Common Reporting Standards, which allow for the automatic exchange of information between different countries, could facilitate the source determination in respect of CSPs rendering services in different countries. 


\section{RECOMMENDATIONS}

Further research on solutions to the issues identified in this study (articulated in TABLE 1, TABLE 2 and TABLE 3 ) is recommended. The resolution of these issues could assist in preventing possible loss of normal tax to the South African fiscus, and also provide guidance to prospective taxpayers and tax consultants. In addition, the Act was also recently amended to provide for a new withholding tax on cross-border service fees, with effect from 1 January 2016 (National Treasury, 2013). This new withholding tax will be a final withholding tax that will be used to identify and collect revenue from non-resident taxpayers who provide certain services within a South African source that fall outside of normal tax. More specifically, all payments for services to a foreign resident from a South African source will be subject to withholding tax if those services are of a technical, managerial or consultative nature. A further recommendation would be to consider whether electronic services (such as cloud computing services) should be included in the scope of such technical services and thus be subjected to the pending withholding tax on cross-border services.

\section{LIST OF REFERENCES}

Bradshaw, S., Millard, C. \& Walden, I. (2011). Contracts for clouds: comparison and analysis of the terms and conditions of cloud computing services. International Journal of Law and Information Technology, 19(3), pp. 187-223.

Casino Enterprises (Pty) Ltd $v$ The Gauteng Gambling Board 2011 (6) SA 614 (SCA). 653/10. (28 September 2011).

Clearley, D.W., Scott, D., Skorupa, J. \& Bittmann, T.J. (2013). Top 10 technology trends, 2013: cloud computing and hybrid IT drive future IT models. (Gartner Research Report). Available:

https://www.gartner.com/doc /2328816/top--technology-trends (Accessed 19 December 2013).

Commissioner of Inland Revenue v Epstein 1954 (3) SA 689(A). (25 May 1954).

Commissioner of Inland Revenue v Lever Brothers and Another 1946 AD 441. (30 March 1946).

Commissioner of Taxes v British United Shoe Machinery (SA) (Pty) Ltd 26 SATC 163. (13 April 1964).

Commissioner of Taxes v Shein 1958 (3) SA 14 (FC). (18 March 1958).

Ernst \& Young. (2012). Tax considerations in cloud computing. Global survey report. Available: http://www.ey.com/Publication/vwLUAssets/Tax_considerations_in_cloud_computing_global_surve y/\$FILE/Cloud_computing_survey_results.pdf (Accessed 19 December 2013).

Fifth Interim Report of the Commission of Inquiry into Certain Aspects of the Tax Structure of South Africa. (1997). Available: http://www.polity.org.za/polity/govdocs/commissions/katz-5.html (Accessed 24 June 2014).

Hellerstein, W. \& Sedon, J. (2012). State taxation of cloud computing: a framework for analysis. Journal of Taxation, 117(1), pp. 11-31. 
Hutchinson, T. \& Duncan, N. (2012). Defining and describing what we do: Doctrinal legal research. Deakin Law Review, 17(1): pp. 83-119.

ITIL, vide Information Technology Infrastructure Library.

Information Technology Infrastructure Library. (2011). Glossary and Abbreviations. Available: http://www.itil-officialsite.com (Accessed 19 December 2013).

Joubert, B. (2012). Tax implications of cloud computing. Deloitte SA Blog. Available: http://deloitteblog.co.za (Accessed 19 December 2013).

Kshetri, N. (2010). Cloud computing in developing economies. Computer, 43(10), pp. 47-55.

KPMG International. (2012). Tax in the cloud. A briefing for tax directors. Available: http://www.kpmg.com/global/en/issuesandinsights/ (Accessed 19 December 2013).

Mell, P. \& Grance, T. (2011). The NIST definition of cloud computing. National Institute of Standards and Technology, Maryland, USA. (Special Publication 800-145).

Meyerowitz, D. (2005). Meyorowitz on normal tax, 2005-2006 edition. Cape Town: The Taxpayer.

$0 \varepsilon C D$, vide Organisation for Economic Co-operation and Development.

Organisation for Economic Co-operation and Development. (2012). Commentary on Article 12:

Concerning the taxation of royalties. (Model Tax Convention on Income and on Capital 2010: Full Version, 0ECD Publishing). Available: http://dx.doi.org/10.1787/9789264175181-46-en (Accessed 19 December 2013).

Organisation for Economic Co-operation and Development. (2015). The CRS Implementation Handbook. Available: http://www.oecd.org (Accessed 17 December 2015).

Ogutto, A.W. \& Van der Merwe, B. (2005). Electronic commerce: challenging the income tax base. South African Mercantile Law Journal, 17(3), pp. 305-322.

0'Sullivan, J., Edmond, D. \& Ter Hofstede, A.H.M. (2002). What's in a Service?^ Towards Accurate Description of Non-Functional Service Properties. Distributed and Parallel Databases, 12(2-3), pp. 117-133.

Plummer, D.C., Smith, D.M., Bittman, T.J., Clearley, D.W., Cappuccio, D.J., Scott, D., Kumar, R. \& Robertson, B. (2009). Five refining attributes of public and private cloud computing. (Gartner Research Report, 5 May 2009). Available:

http://my.gartner.com/resources/167100/167182/five_refining_attributes_of_167182.pdf. (Accessed 19 December 2013).

South Africa. (1962). Income Tax Act, No. 58 of 1962 [as amended]. Pretoria: Government Printer.

South Africa. (2013). National Treasury. Explanatory Memorandum of the Taxation Laws Amendment Bill 2013. Pretoria: Government Printer.

South Africa. (2014). National Treasury. Government Notice: Regulations prescribing electronic services for the purpose of the definition of 'electronic service' in section 1 of the Value-Added Tax Act. Pretoria: Government Printer.

SARS, vide South African Revenue Service.

South African Revenue Service. (2013). Explanatory memorandum on the taxation laws amendment bill, 2013. Pretoria: South African Revenue Service. 
Smith, D.M. \& Clearley, D.W. (2012). Agenda for cloud computing, (Gartner Research Note, 22 February 2012). Available:

http://my.gartner.com/portal/server.pt?open=512\&objID=260\&mode=2\&PagelD =3460702\&res Id = 193 $1114 \&$ ref=QuickSearch\&sthkw=cloud+computing (Accessed 19 December 2013).

Steenkamp, S. (2014). An investigation of the normal tax consequences for non-resident cloud computing service providers in South Africa. Unpublished Master's thesis. Stellenbosch: Stellenbosch University.

Van der Walt, A.J. \& Pienaar, G.J. (1999). Inleiding tot die Sakereg, $3^{\text {de }}$ uitgawe. [Introduction to Law of Things, $3^{\text {rd }}$ ed]. South Africa: Juta and Co. Ltd.

Van Zyl, L. (2015). Residence and Source. In Stiglingh, M. (ed.) Silke: South African Normal tax. South Africa: LexisNexis, pp. 59-91.

Wesson, N. (1999). Die invloed van internet op die toepaslikheid van die bronreëls in terme van die Inkomstebelastingwet, no. 58 van 1962. [The effect of Internet on the applicability of source rules in terms of the Income Tax Act, no. 58 of 1962]. Unpublished Master's thesis. Stellenbosch: Stellenbosch University. 